\title{
Integrating fishing spatial patterns and strategies to improve high seas fisheries management
}

\author{
Vilela, $\mathbf{R}^{1 *}$, Conesa, D. ${ }^{2}$, del Rio, J.L. ${ }^{3}$, López-Quílez, A. ${ }^{2}$, Portela, J. ${ }^{3}$, Bellido, J.M. ${ }^{1}$ \\ ${ }^{1}$ Centro Oceanográfico de Murcia. Instituto Español de Oceanografía. C/ Varadero, 1. 30740. San Pedro del Pinatar, \\ Murcia (Spain) \\ ${ }^{2}$ Departamento de Estadística e Investigación Operativa. Universidad de Valencia. C/ Dr. Moliner 50, Burjassot. \\ Valencia (Spain) \\ ${ }^{3}$ Centro Oceanográfico de Vigo. Instituto Español de Oceanografía. Subida al Radiofaro 50. 36390. Vigo (Spain) \\ *Corresponding author: tel +34 968179411; fax: +34 968184441; e-mail: raul.vilela@mu.ieo.es
}

Keywords: VMEs, High Seas, Southwest Atlantic, Fishing strategy, Marine Spatial Planning

\begin{abstract}
Fishing activity in waters beyond national jurisdiction generates multiple management issues, such as data poor fisheries, management of straddling fish stocks and lack of impact assessments on deep-sea Vulnerable Marine Ecosystems (VMEs). Fishing strategy is the key to understanding and managing high seas fisheries, targeting highly migratory resources that are widely distributed. An international fleet, including Spanish flag bottom trawlers, operates along the Patagonian shelf in Southwest Atlantic waters, which includes an unregulated strip of continental shelf beyond national jurisdiction. The Spanish fleet's fishing strategy was analyzed, and based on on-board observer data collected from 1989 to 2015, three main fishing seasons were identified: a first season mainly targeting Argentinean squid (Illex argentinus) from January to March, a second season targeting hake (Merluccius hubbsi) from April to August, and a third season from September to December showing an opportunistic and heterogeneous behavior. Findings were framed within current knowledge on resource distribution. A preliminary observation of the inter-annual CPUE rates of target species during their respective fishing seasons highlights the possible existence of species linkages and bioclimatic cycles which may affect species distribution and abundance in the area and might require future research. Even if current fishing activity from the Spanish fleet does not overlap deep-water VMEs, any slight change in the fishing strategy to deeper waters (i.e. the fleet targeting high density I. argentinus areas below $300 \mathrm{~m}$, or a change in the target species) would be critical for the conservation of VMEs in these waters.
\end{abstract}




\section{Introduction}

The management of fishing activities in the high seas (areas beyond national jurisdictions) is a major challenge, not only for the sustainability of straddling stocks (Bjørndal and Munro, 2007) but also for the conservation of deep-sea Vulnerable Marine Ecosystems (VMEs) (FAO, 2008; Koslow et al. 2000, 2001; Davies et al. 2007), especially cold-water corals (Hall-Spencer et al., 2002; Freiwald and Roberts, 2006). These issues were acknowledged by the United Nations General Assembly (UNGA), adopting resolutions 61/105 (UNGA, 2007) and 64/72 (UNGA, 2009) calling on flag states and Regional Fisheries Management Organizations (RFMOs) to take immediate actions towards the sustainable management of fish stocks and protection of VMEs from destructive fishing practices, consistent with the 2009 FAO International Guidelines for the Management of Deep-Sea Fisheries in the High Seas (FAO, 2009)

The Southwest Atlantic contains one of the largest continental shelves in the world, even exceeding the Exclusive Economic Zone of coastal countries and thus leaving a strip of unregulated high seas rich in fishing resources. Between 25 and 30 demersal freezer trawlers with the Spanish flag fish each year on the Patagonian shelf, performing their activities both in the high seas of the Patagonian Shelf (hereafter HSPS) and in waters under jurisdiction of the Malvinas/Falklands islands. In addition, the main species targeted in the Patagonian Shelf, such as the Argentinean hake (Merluccius hubbsi), the Argentine short fin squid (Illex argentinus) or the Patagonian squid (Doryteuthis gahi), belong to trans-zonal stocks which extend throughout the continental shelf, being caught either in the Argentinean EEZ, in Malvinas/Falklands waters or in the HSPS. However, in practice, and mainly because of political issues, there is no RFMO operating in the region for the shared management of the resources, although previous attempts have been made in this regard.

Since 1991, due to Argentinean territorial claims and the northern extension of the FOCZ (Falklands Outer Conservation Zone), HSPS waters were almost limited to the so-called 
'Division 46' (Portela et al., 1997) (Figure 1). Research on fishing activity and yields in this fishing ground have been confined to studies based on logbook data from the Taiwanese squid fishery (Chen et al., 2007a; Chen et al., 2007b, Chen et al., 2009) and on-board observer data for the Spanish trawling fishery (Arkhipkin et al., 2003; Sacau et al., 2005; Portela et al., 2005a; Wang et al., 2007). However, none of them offered insights into the fishing strategies of the fleet.

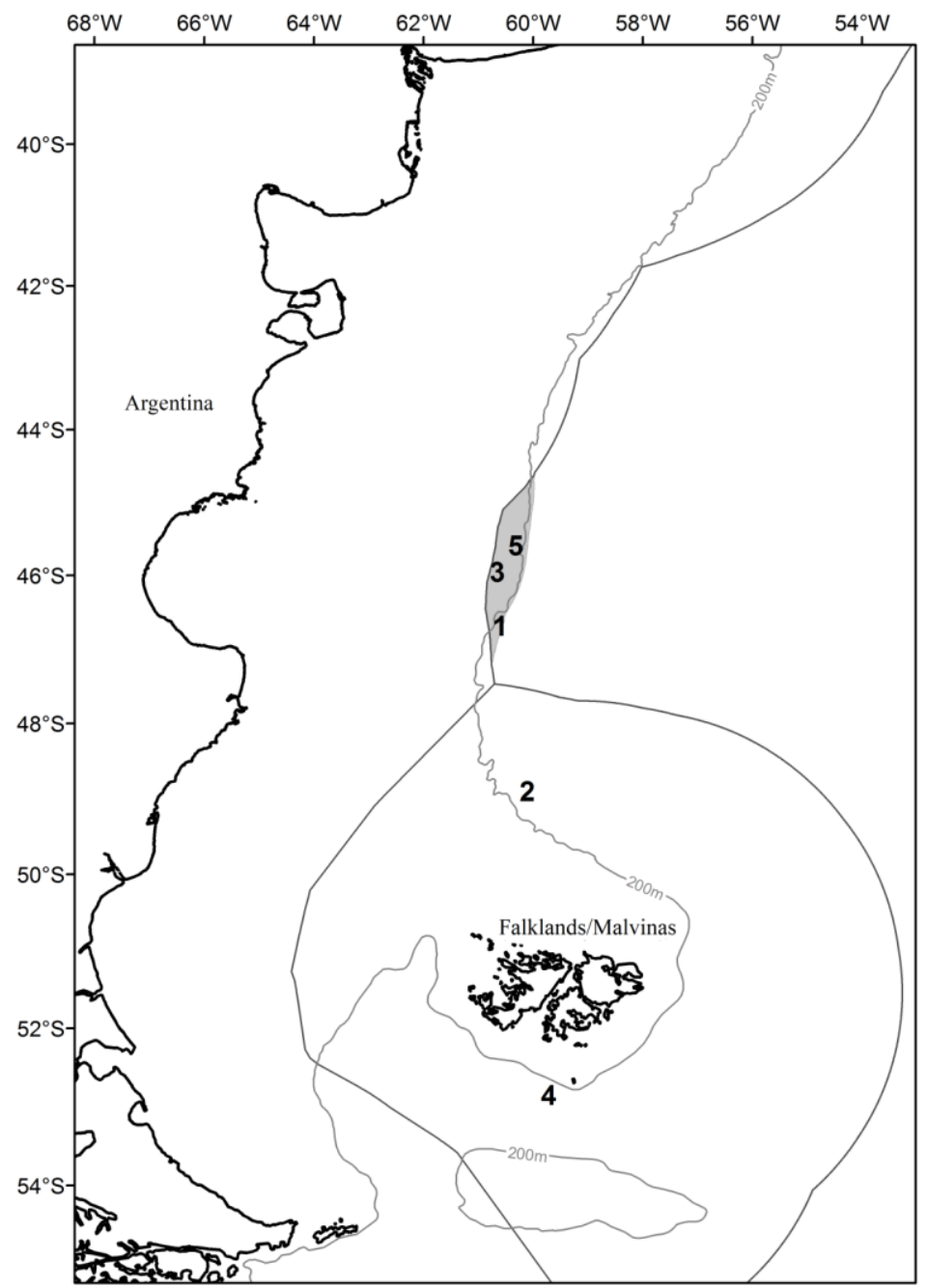

Figure 1. Location of Division 46 (in grey). The 200-meter bathymetric contour, indicating the continental shelf border, and EEZ limits are shown as reference. Overall strategy trends are shown: 1) Fleet targeting $I$. argentinus in the high seas slope between January and March; 2) I. argentinus fishing season in Falklands/Malvinas waters between mid-February and May; 3) Fleet targeting M. hubbsi in the high seas continental shelf between April and August; 4) Second fishing season in in Falklands/Malvinas waters, mainly targeting the $D$. gahi season between July and September and the hake season between August and September; 5) Opportunistic fishing strategy in the high seas continental shelf between September and December, mainly targeting hake at lower yields. 
Marine resource distribution in the region is heavily influenced by oceanographic features of the Patagonian shelf itself; in particular the HSPS comes under the direct effect of the Malvinas/Falklands current and the Patagonian shelf break front (Acha et al. 2004). In addition, tidal fronts on the continental shelf, fresh water discharge from the River Plate, and the BrazilFalklands currents confluence play an important role in species recruitment and the distribution of commercial stocks fished in the region (Otero et al., 1981; Podestá, 1990; Haimovici and Álvarez-Pérez, 1990; Sabatini and Colombo, 2001; Louge et al., 2009).

A series of 13 multi-disciplinary research cruises carried out by the IEO in the HSPS between the years 2007 and 2010 identified aggregations of cold-water corals at depths of between 400 and 1000m, colonized by many other species (Portela et al., 2015), high diversity coral garden communities between 300 and 500m depth, sponge aggregates between 250 and $1300 \mathrm{~m}$ depth and a number of deep marine rocky environments. These series of surveys also allowed for the first time a stock assessment to be performed from independent data of marine resources in the area (Portela et al., 2010; STECF, 2012) and the impact of fisheries on VMEs to be assessed (Portela et al., 2015).

Even if the overlap of VMEs with current fishing operations was found to be almost negligible, it remained unknown whether this absence was a consequence of the impact of previous fishing activities. On the other hand, the distribution of current and potentially commercial species actually overlapped deep-water VMEs, and therefore any change in the fishing strategy of the fleet (i.e. a change of target species or deep-water fishing) might directly impact VMEs in the area. Correct identification of the fishing strategy may help to support management plans to protect high seas singular ecosystems where fishing activity occurs or may occur.

However, detailed multi-disciplinary studies of this kind are infrequent in high seas waters, and therefore fishery dependent data, together with effort estimated from VMS (Vessel Monitoring 
System) data, are still the only data sources available for a number of industrial fisheries worldwide. These data sources are nevertheless a valuable asset for determining fishing strategy, identifying the presence of VMEs (Taylor et al., 2013; Parker et al., 2009; FAO, 2009) and estimating spatial-temporal changes in the stock of target and by-catch species (Lunn and Dearden 2006; EC 2010).

Both prior knowledge of fishing behavior and understanding of the fishery are crucial not only for establishing a correct strategy for analyzing dependent fishery data, but also for assessing potential impacts of bottom trawling activities and supporting the proper management of the fishing activity. Here, two aspects of the fishery were analyzed; firstly, to identify of the general fishing strategy followed by the Spanish fleet operating in Southwest Atlantic waters (i.e. number of units, main fishing grounds and general pattern); and secondly, to determine the specific fishing pattern performed by the same fleet on the High Seas of the Patagonian Shelf, identifying target species, fishing seasons and the main characteristics of the fishing operations during each of the identified fishing seasons. Results were placed in context with the current understanding of regional fishing resource distribution and seasonal oceanographic features. Finally, these findings were used to estimate inter-annual biomass trends from fisherydependent CPUE (in kilograms/hour) and assess potential impacts of changes in the fishing strategy in deep-water VMEs.

\section{Material \& methods}

The fishing data analyzed belong to a series of 27 years, from 1989 until 2015, of the Spanish on-board observer program for commercial fishing vessels in Southwest Atlantic waters. During this period, observers were present on about $14 \%$ of the Spanish fishing vessels reported operating in this region, sampling a total of 30294 hauls. 
Of these, 11841 hauls from 158 fishing trips and 69 different vessels were sampled in 'Division 46' of the HSPS the fishing activity in question mainly being performed at depths of between 100 and 300 meters, covering an extension of approximately $300 \mathrm{~km}$ from north to south, and 50 kilometers from east to west, from $44^{\circ} 50^{\prime} \mathrm{S}$ to $47^{\circ} 24^{\prime} \mathrm{S}$.

The information collected refers to coordinates and time-date records of the haul starting and ending points, catch and discard composition and other relevant information about the fishing operation. In addition, size, weight and maturity stage samples for retained and discarded species were also collected systematically. Other data sources used were the historic registry of fishing vessels fishing in SW Atlantic waters kept by the fishing-boat owners' association ANAMER ('Asociación Nacional de Armadores de Buques Congeladores de Pesca de Merluza') and the vessel registry of the SGP ('Secretaria General de Pesca').

The use of CPUE from commercial fisheries, however, often prompts difficulties in the choice of a suitable statistical approach. Nevertheless, by an appropriate selection of specific timewindows, the CPUE of target species can be used as an index of change of abundance, allowing us to explore relationships with the environment (i.e. Lehodey et al., 1997; Chang et al., 2010; Escalle et al., 2016), while avoiding over-inflation of zero values usually associated with this type of data (Maunder and Punt, 2004; Zuur et al., 2007, Zuur et al., 2010).

With such an approach there is no need to use two step (occurrence-abundance) models (Paradinas et al., 2015; 2017), but the following conditions have to be met: (1) homogeneity of the fishing fleet (Hilborn and Walters, 1992); (2) actual presence of resource in the fishing area and (3) fishing effort effectively focused on the resource catch (Maunder and Punt, 2004). In the case of by-catch species, their abundance can be directly related to the observed CPUE (Pennino et al., 2014). 
General fishing strategy was described by means of a general overview of the temporal variation of the number of units fishing in SW Atlantic waters. Changes in the number of units were interpreted on the basis of expert knowledge of the fishery and placed within context.

Then, hauls performed in the HSPS were analyzed. Main targeted species and presence of the species in the fishing area were identified by means of monthly absence ratios (the species is present) and CPUE, catch and discard composition (the species is being targeted). Changes over time in the species being targeted were visualized using level plots of the ratio over the total retained catch for each species by month and year (i.e. retained catch for a given species divided by the total retained catch), the ratio ranging between 0 (the species is fully discarded) and 1 (the species composes 100\% of the retained catch). Groups of months with similar CPUE per species composition were assessed by means of a hierarchical cluster analysis, using Ward's Clustering Method (Jabeur et al., 2000; Pelletier and Ferraris, 2000; Tzanatos et al., 2005) In addition, main fishing operation characteristics were described by season, including average haul length, proportion of night/day hauls and footprint of the fishery. The latter was calculated using the line density tool of ArcMap 10.3 (ESRI, 2016), for which fishing operations were assumed to be straight lines between the start and end coordinates.

Following the description of the fishing strategy in the HSPS, annual trends in the CPUE (in kilograms/hour) of main caught species were estimated. For targeted species, only those months when the species were effectively present in the fishing zone and were a confirmed target of the fishery were considered. Inter-annual graphs were constructed for each of the main species, adding regression lines and 95\% confidence intervals using the ggplot2 package (Wickham, 2016) and the 'loess' method (Cleveland, 1979). Possible linkages between species were assessed by means of a Kendall's tau-b correlation coefficient (Kendall, 1955). All analyses were performed using R statistical software (R development Core Team, 2017). 


\section{Results}

\subsection{Fishing activity trends of the Spanish fleet in SW Atlantic waters}

Vessel characteristics of the Spanish freezing trawlers fishing in Southwest Atlantic waters were relatively homogeneous, bearing in mind the wide temporal range of the series, averaging 63,6 meters in length ( $\pm 8 \mathrm{~m} \mathrm{SD}), 1856$ horse power $( \pm 322 \mathrm{hp} \mathrm{SD})$ and 1222 Gross Ton ( \pm 322 GT SD) with a mean storage capacity of 1337 cubic meters $\left( \pm 404 \mathrm{~m}^{3} \mathrm{SD}\right)$.

The annual number of units fishing in SW Atlantic waters reported by ANAMER reached its peak in 1990 with 79 units (Figure 2), although estimations from the IEO would place the real number of Spanish fishing vessels that year at 100 units (Portela, 2009). After 1990, the number of fishing vessels decreased until its minimum in 2001 (18 units), and thereafter steadily recovered until its number stabilized in 2006 at around 23-26 fishing vessels.

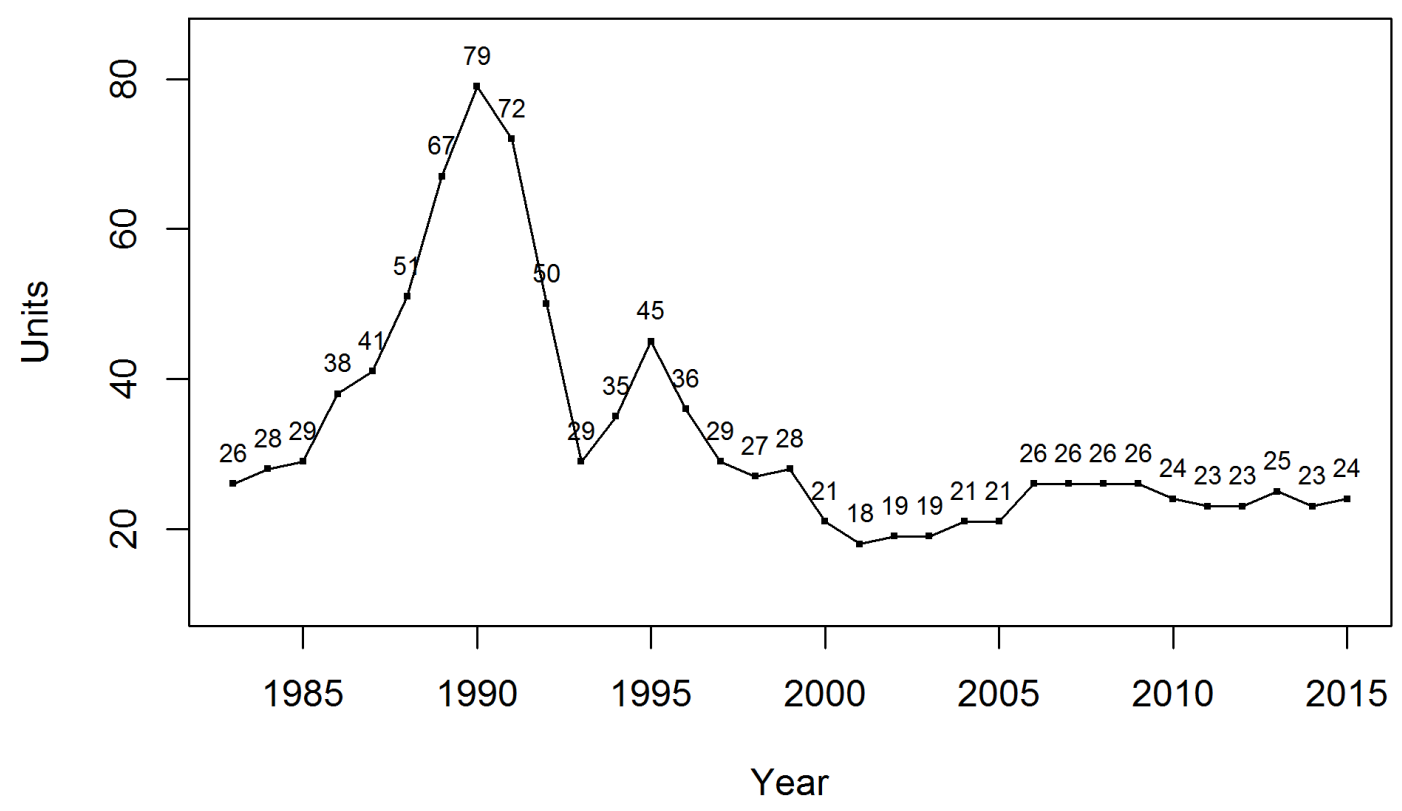

Figure 2. Number of vessels fishing in SW Atlantic waters between the years 1983 and 2015.

Fishing activity was shared between Malvinas/Falkland waters and the HSPS, accounting for $56.2 \%$ and $43.8 \%$ of the 30294 observed hauls, respectively. Most of the fishing activity was 
performed in Malvinas/Falkland waters, with peaks of activity during April-May and

September-October, preceded by peaks of activity in the HSPS during March-April and AugustOctober (Figure 3).

Since $1991,97 \%$ of the fishing activity in the HSPS has been performed uniquely in 'Division 46 ', the remaining $3 \%$ belonging to isolated hauls performed in 'Division 42 ' on the way to/from the fishing grounds to the port of Montevideo in Uruguay. From then on, all analyses regarding HSPS were confined to the 'Division 46' area.

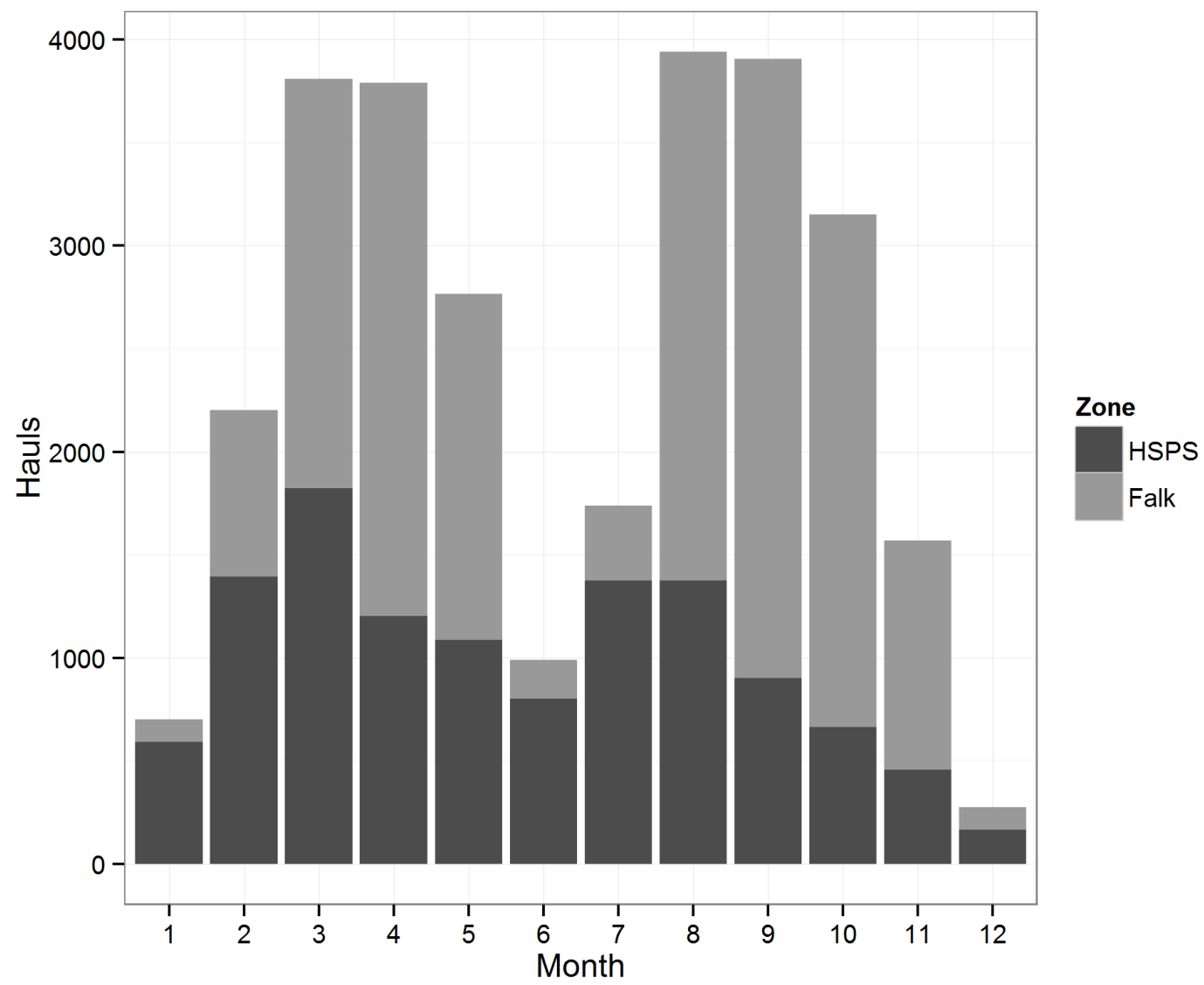

Figure 3. Stacked barplot showing the number of hauls recorded by the observer program by fishing zone between 1989 and 2015 in Falklands/Malvinas waters (light grey) and in the high seas of the Patagonian Shelf (dark grey).

\section{2. $\quad$ Catch composition and seasonal yield trends in the HSPS}


The main species caught in the HSPS were Merluccius hubbsi (44.2\% of the total catch), Illex argentinus (28.6\% of the total catch) and Patagonotothen sp. (mostly P. ramsayi; $17.7 \%$ of the total catch), the latter being highly discarded (Table 1). 90.6\% of the total catches in the HSPS between 1989 and 2015 belong solely to these three species, being the overall discard rate for the fishery being around $17 \%$.

Table 1. Total catch (tons), discards (tons), percentage of total catch and discards over the species total catch for the five main caught species in Division 46.

\begin{tabular}{c|ccccc}
\hline Species & $\begin{array}{c}\text { Tot. } \\
\text { Catch }\end{array}$ & \% Tot. catch & Disc. & \% Tot. disc. & \% Disc. \\
\hline M. hubbsi & 29,560 & 44.2 & 656 & 5.6 & 2.2 \\
I. argentinus & 19,108 & 28.6 & 460 & 3.9 & 2.4 \\
Patagonotothen sp. & 11,831 & 17.7 & 8,743 & 74.6 & 73.8 \\
D. gahi & 2,062 & 3.1 & 20 & 0.1 & 1.0 \\
G.blacodes & 1,997 & 3.0 & 156 & 1.3 & 4.6 \\
Others & 2,183 & 3.3 & 1,678 & 14.3 & - \\
\hline TOTAL & 66,741 & 100 & 11,713 & 100 & 45.7 \\
\hline
\end{tabular}

Monthly absence ratios (i.e. ratio of number of hauls without catch) by species are shown in

Table 2, confirming hake as the most prevalent species in the HSPS and averaging less than $10 \%$ of hauls with absence of this species for the whole period. In addition, daily variations were found in both catch quantities and catch composition, between diurnal and nocturnal sets. During daylight periods, the most widely-caught species were $M$. hubbsi, followed by $I$. argentinus, Patagonotothen sp., D. gahi and Genypterus blacodes, whilst a considerable fall-off in catch quantity was found during night sets, the most caught species in this case being $M$. hubbsi, followed by Patagonotothen sp, I. argentinus, G. blacodes and Patagonotothen maculatus. 
Table 2. Number of hauls sampled by month ( $\mathrm{N}$ hauls), and number of hauls with catch equal to 0 (hauls no catch) and absence ratio (Ratio abs.) are shown for the three main species caught in the Division 46 zone. Absence ratios of less than $5 \%$ (high presence of the species) are highlighted in bold type.

\begin{tabular}{|c|c|c|c|c|c|c|c|}
\hline \multirow[t]{2}{*}{ Month } & \multirow[t]{2}{*}{$\mathbf{N}$ hauls } & \multicolumn{2}{|c|}{ M. hubbsi } & \multicolumn{2}{|c|}{ Patagonotothen sp. } & \multicolumn{2}{|c|}{ I. argentinus } \\
\hline & & $\begin{array}{c}\text { Hauls no } \\
\text { catch }\end{array}$ & $\begin{array}{c}\text { Ratio } \\
\text { abs. }\end{array}$ & $\begin{array}{c}\text { Hauls no } \\
\text { catch }\end{array}$ & $\begin{array}{l}\text { Ratio } \\
\text { abs. }\end{array}$ & $\begin{array}{c}\text { Hauls no } \\
\text { catch }\end{array}$ & $\begin{array}{c}\text { Ratio } \\
\text { abs. }\end{array}$ \\
\hline Jan & 592 & 69 & 0.12 & 25 & 0.04 & 15 & 0.03 \\
\hline Feb & 1,400 & 358 & 0.26 & 275 & 0.20 & 33 & 0.02 \\
\hline Mar & 1,832 & 332 & 0.18 & 525 & 0.29 & 49 & 0.03 \\
\hline Apr & 1,206 & 25 & 0.02 & 269 & 0.22 & 120 & 0.10 \\
\hline May & 1,086 & 19 & 0.02 & 333 & 0.31 & 185 & 0.17 \\
\hline Jun & 801 & 12 & 0.01 & 195 & 0.24 & 331 & 0.41 \\
\hline Jul & 1,376 & 10 & 0.01 & 335 & 0.24 & 883 & 0.64 \\
\hline Aug & 1,377 & 9 & 0.01 & 386 & 0.28 & 935 & 0.68 \\
\hline Sep & 902 & 65 & 0.07 & 225 & 0.25 & 594 & 0.66 \\
\hline Oct & 664 & 77 & 0.12 & 162 & 0.24 & 395 & 0.59 \\
\hline Nov & 458 & 44 & 0.10 & 32 & 0.07 & 227 & 0.50 \\
\hline Dec & 165 & 44 & 0.27 & 13 & 0.08 & 73 & 0.44 \\
\hline TOT. & 11,859 & 1,064 & 0.09 & 2,775 & 0.23 & 3,840 & 0.32 \\
\hline
\end{tabular}

M. hubbsi showed a clear seasonal pattern. Although discards were almost nonexistent throughout the study period (Table 1), higher yields were achieved during the austral autumnwinter (Table 2 and Figure 4a), especially during the months of June and July (above $700 \mathrm{~kg} / \mathrm{h}$ ). Minimum mean yields were found between December and February (below $200 \mathrm{~kg} / \mathrm{h}$ ); these circumstances remained relatively stable throughout the studied period (Fig. 4a).

Yields of $I$. argentinus also showed a strong seasonality (Table 2 and Figure 4a), as this species was almost only caught during the austral summer (January-March), when mean yield values reached up to $900 \mathrm{~kg} / \mathrm{h}$ and the species was present in more than $98 \%$ of the fishing operations observed. Moreover, the absence ratio increased from July until November, the species being absent in $27 \%$ of the sampled hauls during the month of September. The lowest yields were also 
found in the austral winter (July-October), with mean yields of below $50 \mathrm{~kg} / \mathrm{h}$. Discard rates were very low for this species during the studied period (Table 1). Mean monthly yields remained quite stable until 2003, after which lower retained catches were observed (Figure 4c).

Conversely, yields of Patagonotothen sp. (Figure 4a) showed an inverse seasonal pattern compared with $M$. hubbsi. Yields reached highest values in the austral spring-summer during the month of December, when Patagonotothen sp. showed the lowest absence rates and the highest yields of the year (mean average yield above $700 \mathrm{~kg} / \mathrm{h}$ ). However, during the rest of the year, absence levels constantly exceeded $20 \%$ of the hauls (Table 2). The species was almost entirely discarded throughout the whole year (Table 1), although in recent years it has started to be retained on board, specifically during the last months of the year (Figures $4 \mathrm{~b}$ and $4 \mathrm{c}$ ), when both hake and squid yields are lower.

\subsection{Annual fishing trends}

The time series of the annual average CPUE by target species fishing season in the HSPS (April - August for M. hubbsi, January - March for I. argentinus and, as a by-catch species, all year round for Patagonotothen sp.) are shown in Figure 4c.

No appreciable overall trend was observed in the annual yields for $M$. hubbsi, although two lowyield periods were identified between1998-2001 and 2007-2012. Similarly, yields for $I$. argentinus did not show significant trends, although inter-annual fluctuations were observed, with two high-yield peak periods during the years 1999-2000 and 2007-2008. Yields for Patagonotothen sp. showed a slight upward trend until 2013, when average yields suddenly increased from $347 \mathrm{~kg} / \mathrm{h}$ to $948 \mathrm{~kg} / \mathrm{h}$. 
Kendall's rank correlation tau value for average annual yields for $M$. hubbsi and I. argentinus shows a significant ( $\mathrm{p}$-value: 0.0128 ) negative correlation of -0.339 , indicating an inverse relation between both species. 

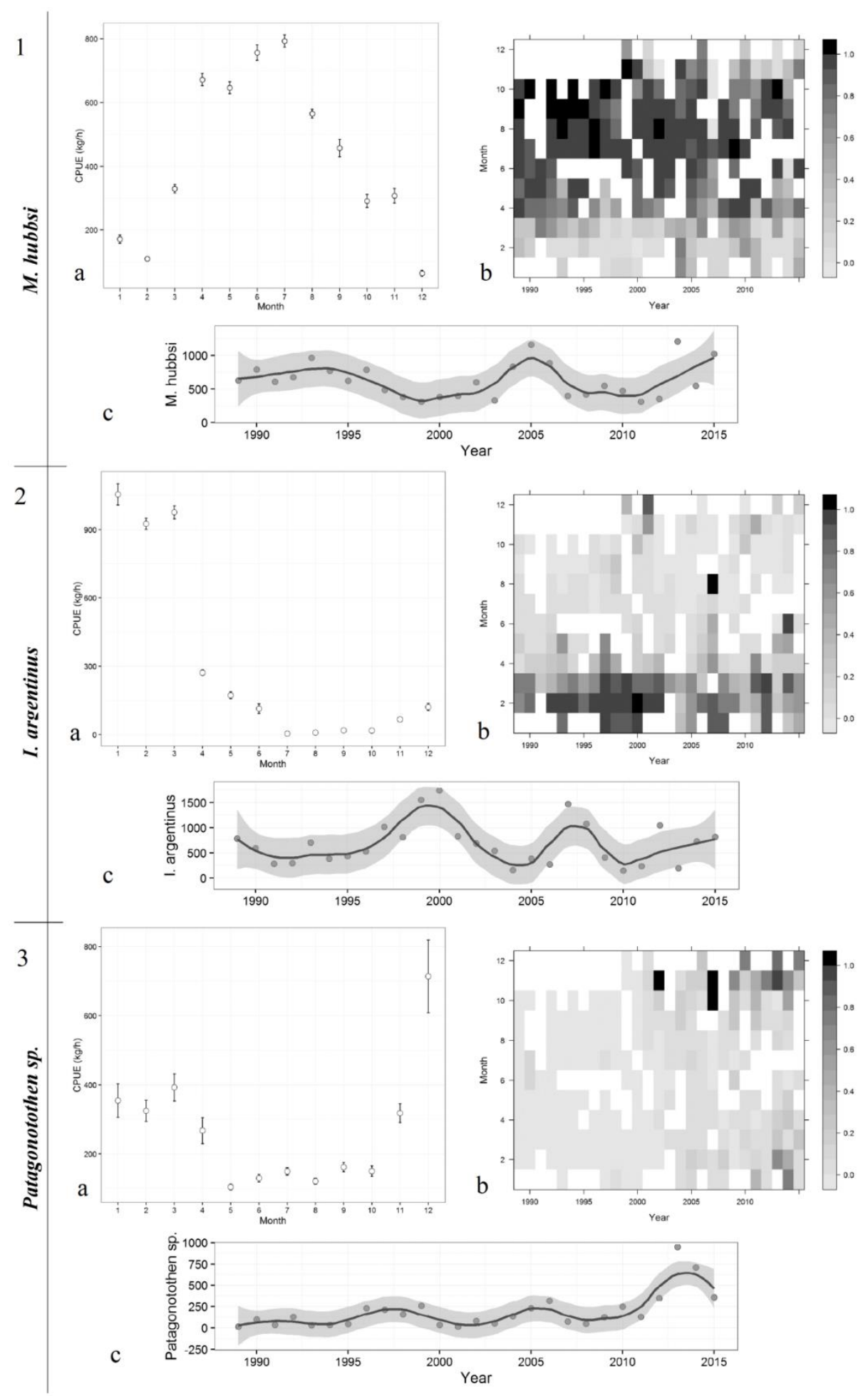

Figure 4. Temporal variability for the main caught species in Division 46: (1) M. hubbsi; (2) I. argentinus; and (3) Patagonotothen sp. For each species the following are shown:

a) Average monthly yields with $95 \%$ interval confidence levels

b) Level plot of the mean ratio over the total retained catch by month and year (where 1 means that all the retained catch belongs to the species, and 0 means that all the retained catch belongs to other species. c) CPUE annual trends. Only months when the species are considered to be a target of the fishery are considered when constructing the trend. The full year has been used for Patagonotothen $s p$. The shaded area represents the $95 \%$ interval confidence zone. 


\subsection{Hierarchical cluster analysis}

Results from the hierarchical cluster analysis (Figure 5 and Table 3) confirm previous observations, identifying 3 main fishing seasons based on the yields by haul observed for the three main species. The first from January to March, characterized by high yields of $I$. argentinus and regular values of $M$. hubbsi and Patagonotothen sp.; the second between April and August, characterized by high yields of $M$. hubbsi and low yields of I. argentinus; and the third season between September and December, showing high yields of Patagonotothen sp. and low yields of $M$. hubbsi.

Table 3. Groups of months identified by the cluster analsyis and CPUE median values by group and species in kg/hour.

\begin{tabular}{c|c|ccc}
\hline Group & Months & M.hubbsi $(\mathbf{k g} / \mathbf{h})$ & I. argentinus $(\mathbf{k g} / \mathbf{h})$ & Patagonotothen sp. $(\mathbf{k g} / \mathbf{h})$ \\
\hline 1 & Jan. - Mar. & 48 & 674 & 53 \\
2 & Apr. - Aug. & 513 & 5 & 30 \\
3. & Sept. - Dec. & 146 & 0 & 55 \\
\hline
\end{tabular}




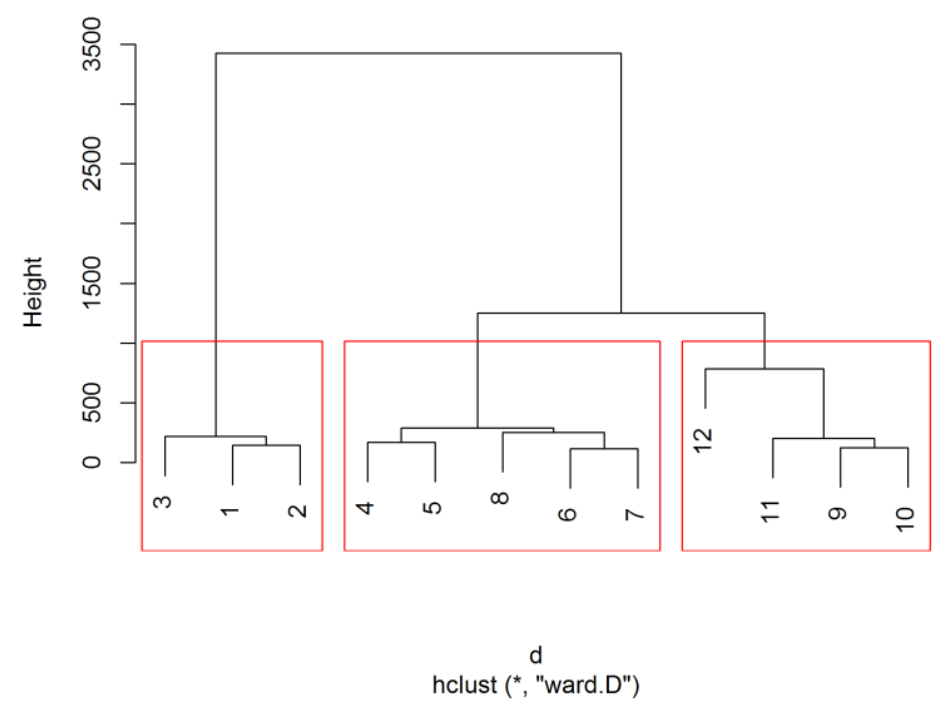

Figure 5. Groups of months obtained by hierarchical cluster analysis using Ward's minimum variance agglomeration method, where the Euclidean distance matrix is based on yields per haul observed for the three main caught species.

\subsection{Characteristics of the fishing operations}

Shorter hauls were performed during the first season (5.13 hours on average; Figure 6a), whereas average trawling duration during the second season was 6.1 hours. The longest fishing operations were found during the third season (6.2 hours on average), showing high variability in December. In addition, daylight hauls were, on average, longer than night time hauls regardless of the season or species targeted (Figure 6b). 

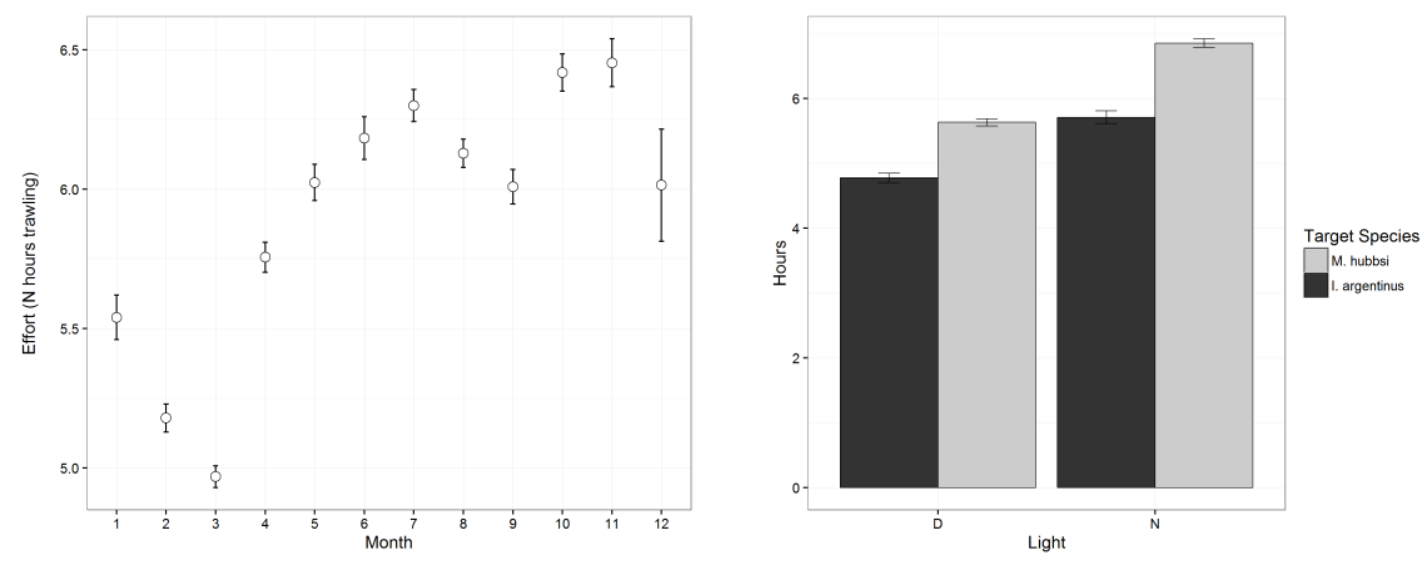

Figure 6. Left: Monthly fishing effort expressed as average haul length in hours. $95 \%$ interval confidence levels are shown to express monthly effort variability. Right: average haul length according to target species and daylight period (D: day; N: night)

From a spatial point of view (Figure 7), fishing operations during the first fishing season were performed predominantly on the southern slope between 140 and $250 \mathrm{~m}$ depth, while fishing operations performed during the second fishing season were more widespread and performed preferentially on the continental shelf between 110 and $150 \mathrm{~m}$ depth. 

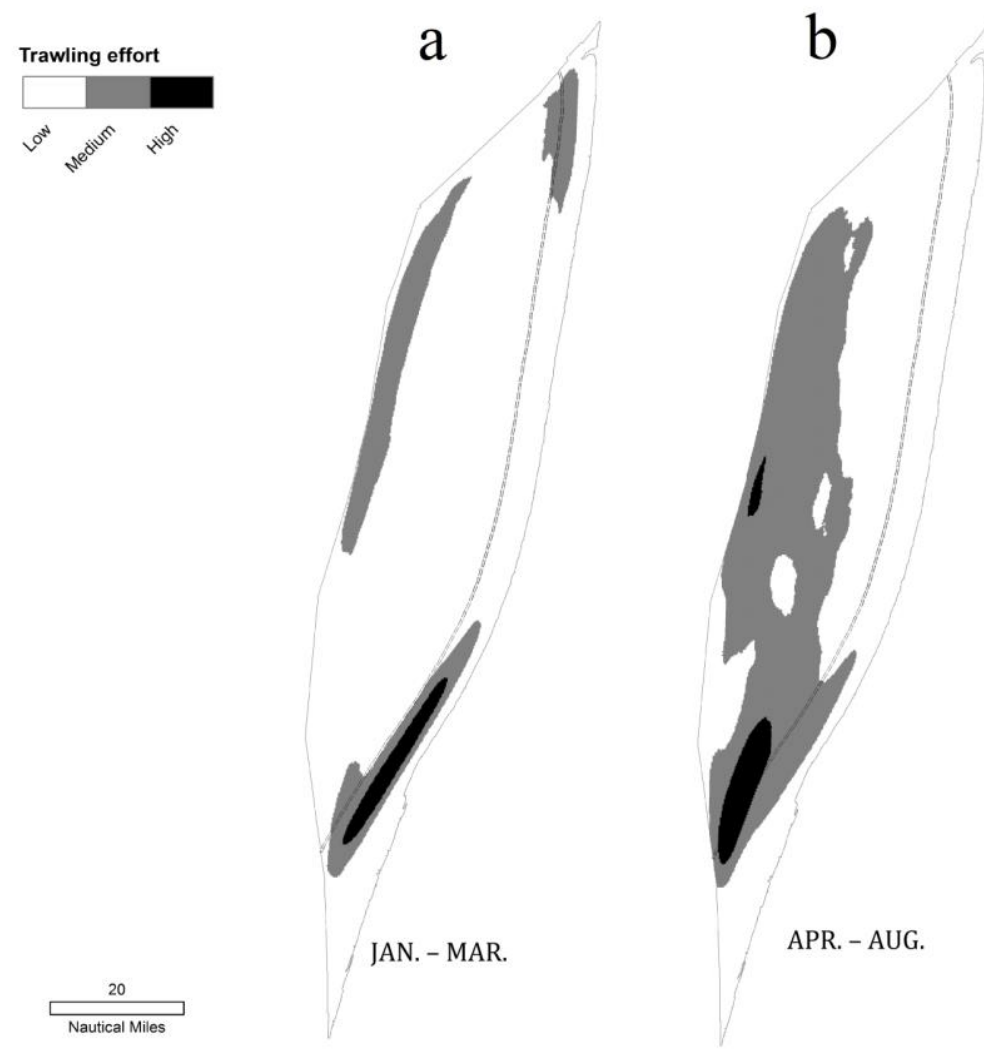

Figure 7. Categorized fishing effort performed between 1989 and 2015 in Division 46 during (a) the $I$. argentinus fishing season in January- March and (b) the M. hubbsi fishing season in April-August. Deep waters are at the right-hand side of the maps. Slope limit is marked with a double dashed line.

\section{Discussion}

\subsection{Overall fishing strategy pattern in Southwest Atlantic waters}

The strong seasonality in the number of hauls observed in 'Division 46' and in

Malvinas/Falkland waters and the relation between them suggests a fishing activity mainly focused on the Malvinas/Falkland fisheries, changing to the high seas between fishing periods, mainly before the beginning of the latter. This behavior fits with the migratory fluxes of the exploited resources in the region, mainly following the South-Patagonian stock (SPS) of $I$. argentinus on its migration towards the south (Agnew et al., 2005; Rodhouse et al., 1995; Basson et al., 1996). 


\subsection{Overall strategy variation along the studied period}

The evolution of the number of fishing vessels since the 1980s points to yields and external events (e.g. the opening and closing of foreign fisheries to the Spanish fleet) as the main factors determining the number of fishing vessels in the region. More specifically, the increase in units in 1989 is identified with the closing of the fisheries in Namibia, while the decrease in units after 1990 corresponded to several factors: the development of the Greenland halibut fishery in Newfoundland, the shrinking squid market and the European policy of fleet reduction (Portela et al., 1997).

Later, an increase was observed in 1995 due to the conflict raised with Canada, when European fishing vessels were forcibly obliged to abandon the fishing grounds of Newfoundland. Once the conflict was resolved, the number of units in SW Atlantic waters decreased again. This effect was boosted by the re-opening of the Namibian fisheries (Portela et al., 2002; Portela, 2009). The stabilization of the number of fishing vessels after 2006 suggests the existence of a specialized segment of the fleet focused on this region.

\subsection{Fishing strategy in the HSPS}

Specifically, most of the catch performed by Spanish freezer trawlers in the HSPS corresponded to only three species: M. hubbsi, I. argentinus and Patagonotothen sp., the latter being considered as a by-catch because of its high number of discards throughout the year. Data suggest that this situation has changed in recent years, although the catch of this species still follows an opportunistic strategy, only being retained when catches of the two main target species decrease.

Most of the fishing activity takes place during daylight periods and a strong daily pattern can be observed in the catch composition, with I. argentinus being caught preferentially during the day. 
This observation is consistent with the typical vertical daily migrations of squids (Roper and Young, 1975), which live near the bottom during the day and ascend to surface waters during the night to feed (Brunetti, 1988).

HSPS can be described as a transit area with a clear annual fishing pattern, particularly for $M$. hubbsi and I. argentinus. The fleet targeted short fin squid during the months of January-March, hake during the months of April-August and, finally, adopts an opportunistic fishing strategy from September to December (see strategy description included in Figure 1). Even if hake continued to be the main target species during this latter period, lower and varying yields were observed, together with a reduction of fishing effort, displacement to Malvinas/Falkland waters (mainly between August and October) and a more heterogeneous catch composition.

\subsection{Putting the fishing strategy in the HSPS into context}

I. argentinus was the species showing the highest seasonality in the HSPS, being caught primarily on the southern slope between January and March. This observation agrees with previous knowledge about the species (Rodhouse et al., 1995; Haimovici et al., 1998; Brunetti et al., 2000, del Rio et al., 2008), placing the HSPS inside the feeding area during the summerautumn periods prior to the species' reproductive migration to southern waters.

Thus, the Illex fishery season in Falkland/Malvinas waters starts in the second half of February, when the first wave of ESPS (Early SPS) squid aggregates in the warm water inflow located in the northern area of the FICZ (Falklands Inner Conservation Zone). Arkhipkin et al. (2013) reported dense feeding aggregations of I. argentinus to the northwest of the Falkland Islands between February and May, with maximum concentrations being observed near the shelf break to the north of the Islands, the highest catch rates being reported in April. 
The inter-seasonal break in the islands during June-July occurs at the end of the first Doryteuthis gahi fishing season by mid-April and after the fall-off of the Illex fishery in May, when the northward migration of the LSPS (Late SPS) commences (Falkland Islands Government, 2014). This situation forces the fleet to move again northward to the HSPS, changing its fleet fishing strategy towards hake, as demonstrated by the few catches of squid during the winter season.

I. argentinus absence rates, and the increase in its discard rates, indicated that this species ceased to be a target species during winter and spring in the HSPS. Instead, it a shift in the fishing strategy was observed, with $M$. hubbsi becoming the most caught species, especially between April and August, and to a lesser extent from September until December.

This change of fishing strategy to $M$. hubbsi was also reflected in the spatial distribution of the hauls; although the main effort continued to be located in the southern area close to the slope border, it was primarily concentrated on the continental shelf. These findings confirmed the observations made by Podestá (1990), Macchi et al. (2004), Pájaro et al. (2005) and Macchi et al. (2007), indicating the presence of this species in deep waters of the continental shelf after February until October.

During the reproductive cycle, hake aggregations displace to $45^{\circ} \mathrm{S}$ to start their movement to deeper waters in February (Macchi et al., 2007), and between May and August this species inhabits the winter fishing grounds, along the outer shelf and continental slope (Podestá, 1990). However, this process is performed in the first place by young spawning females $(35-45 \mathrm{~cm}$ TL), which have a shorter reproductive season than older females (Macchi et al., 2007).

The consequences of this are two-fold: firstly segregation by sex generates a stock differentiation between coastal and oceanic waters during this season, and secondly small mature females are the first individuals of the stock to arrive in the HSPS. Thus, yields of hake during the first months of the year will be lower until the older and larger individuals move to 
the deeper waters of the Patagonian shelf. This happens around March-April, when reproductive activity and individuals disperse on the continental shelf (Macchi et al., 2007).

The second fishing season in Malvinas/Falkland waters occupies the months of August-October, mainly targeting D. gahi between July and September, and hake between August and September (Falkland Islands Government, 2014). This season finishes with the migration of hake to their spawning grounds in October-November, located between $42^{\circ} \mathrm{S}$ and $44^{\circ} \mathrm{S}$ in the shallower waters of the continental shelf, at less than $100 \mathrm{~m}$ depth (Ciechomski et al. 1979, Macchi et al., 2004; Pájaro et al., 2005).

Finally, Patagonotothen sp., contrarily to $M$. hubbsi, increased its abundance in the HSPS during the austral summer. This species was almost fully discarded during the whole of the studied period, the discard rate remaining constant throughout the year, mainly due to its low market value (Winter et al., 2010). Occasionally during the last decade, high rates of retained catch for this species have been observed, especially between November and December, when yields of both M. hubbsi and I. argentinus are at their minimum. Results from the ROCKOD project (Portela et al., 2005b) helped to increase the value of this resource, and nowadays Eastern Europe is the main market of the Patagonotothen sp. retained by the Spanish fleet in SW Atlantic waters (J.L. del Rio, Pers. Comm.).

However, overall it can still be considered as a by-catch species, with no effort being focused on its search and no significant correlation with other target species. In addition, yield trends from observer data can also be interpreted as a credible index proportional to its abundance, although this trend is slowly changing and this species may become a target of the fleet in the near future, depending on market demands and trends in hake and squid yields.

\subsection{Influence of oceanographic and climatic features}


As discussed above, the seasonal strategy of the bottom trawling fleet in Southwest Atlantic waters fully coincides with target species reproductive migration patterns, mainly following $I$. argentinus on its migration north-south, and $M$. hubbsi from shallower inner to deeper outer waters of the continental shelf.

Results of the inter-annual comparison showed the existence of a significant inverse correlation between the annual yields of $M$. hubbsi and I. argentinus, and even though the time series only covered 27 years, it could be considered as an initial sign of inter-annual abundance cycles.

Particularly, for I. argentinus, strong similarities were found with the yield pattern pointed out by Chen et al., (2007a) for CPUEs of Taiwanese jiggers in SW Atlantic waters, indicating a general trend in the abundance of this species for the whole region and a possible linkage with long-term climatic cycles. In this regard, it is worth mentioning that Waluda et al. (1999) noticed the influence of Sea Surface Temperature anomalies in the Pacific on I. argentinus recruitment with a two-year lag. Waluda et al. (2001) also pointed out the role of frontal zones generated between the Malvinas/Falklands current and the continental shelf waters on the aggregations of squid. Both studies reflect the impact of oceanographic features on squid recruitment and distribution, suggesting that this issue should be further explored.

Observations made by Macchi et al. (2010) regarding the reproductive pattern of the Patagonian stock of hake during the month of January between the years 2001 and 2007 indicated a change in 2005 in which the spawning area expanded to deeper waters where the sea-bottom temperature oscillated between $6^{\circ}$ and $8^{\circ} \mathrm{C}$. This spawning group contained a larger proportion of big-sized females than those observed in coastal waters, corresponding to hake females at the end of their reproductive stage migrating to deeper waters, perhaps correlated with the drastic increase in the CPUE of hake observed in the HSPS between 2004 and 2006. This anomalous situation was also observed in Malvinas/Falkland waters (Falkland Islands Government, 2014), where in 2006 the highest annual catch since 1991was recorded, although conversely to the HSPS catches have since remained high in the islands. 
Previous observations (Falkland Islands Government, 2014) suggest the possibility of linkages between the increased abundance of $P$. ramsayi and hake in their feeding grounds northwest of the Malvinas/Falklands islands. Although this study has also found a significant but moderate negative relation between $M$. hubbsi and I. argentinus yields, no long term correlation with $P$. ramsayi could be identified.

Further research is needed not only in this regard, but also as to how these relations might influence the distribution and abundance of commercial species in these waters. For example, displacing fishing effort to deeper waters, or forcing the fleet to change fishing strategy due to a decrease in the catch of main target species (i.e. towards Patagonotothen sp. or Macrourus carinatus).

\subsection{Potential interactions of fishing activities and VMEs}

No potential overlaps were found between VMEs and current fishing strategy (Portela et al., 2012; Portela et al., 2015) or potential distribution for M. hubbsi or Patagonotothen sp. (Portela et al., 2010), and therefore the emerging importance of Patagonotothen sp. as a target should not represent a future threat for the conservation of the VMEs in the region.

However, the abundance of the main target species and potential VME distribution (del Rio et al. 2012) showed potential overlaps between several commercial, or potentially commercial, species and VMEs in the HSPS. Higher abundances of I. argentinus were located in suitable trawling areas up to $700 \mathrm{~m}$ depth (Portela et al., 2010). A change in the current Illex spatial fishing pattern could directly affect the northern and southern VME areas (Figure 8), which should be considered for any future management measure. 


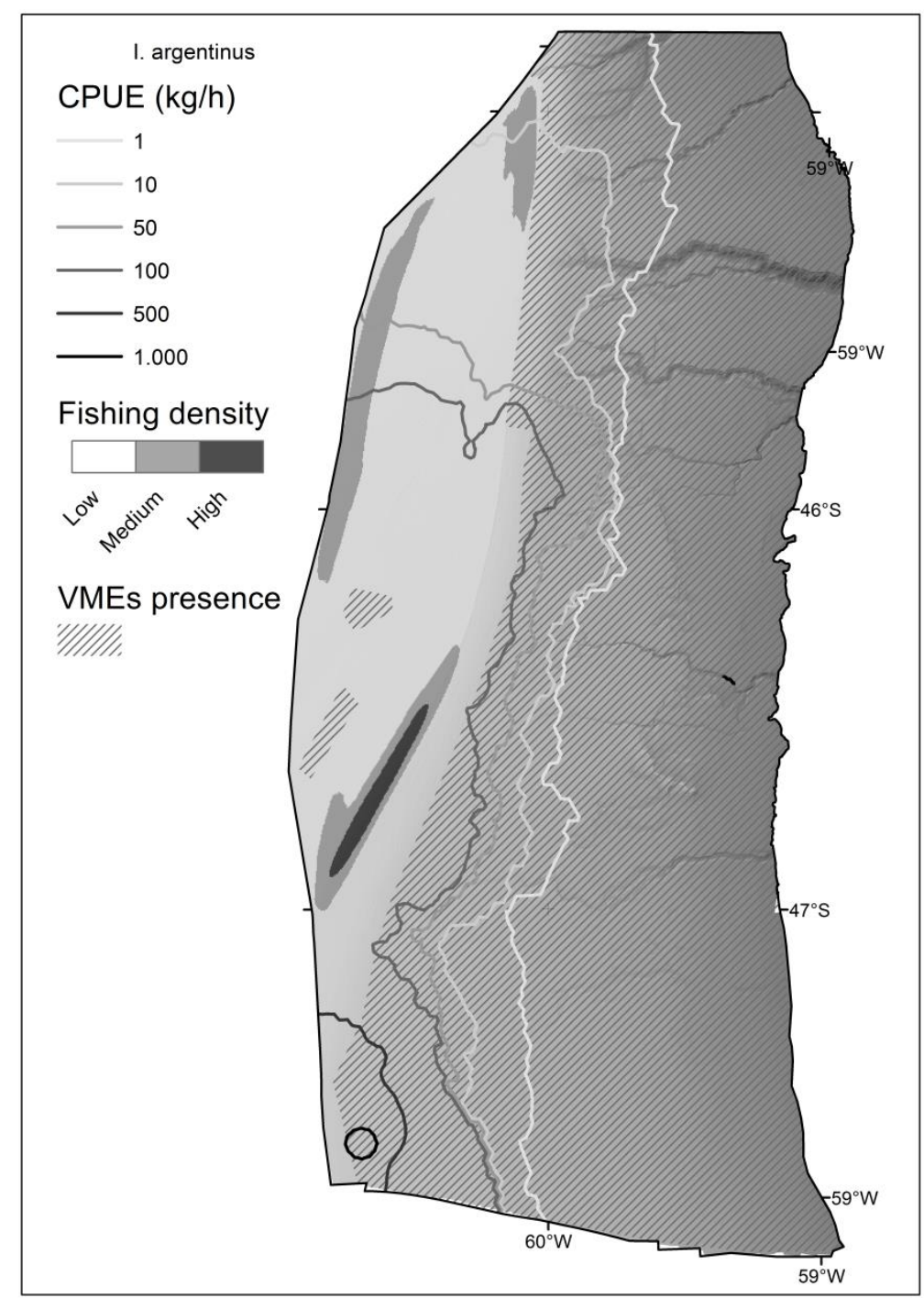

Figure 8. Surveyed area of the HSPS during the PATAGONIA and ATLANTIS series of surveys performed between 2007 and 2010 by the "Instituto Español de Oceanografía". The study area limits to the west with the Exclusive Economic Zone border, to the east with the $1500 \mathrm{~m}$ bathymetric contour, and to the south with the Falkland Outer Conservation Zone (FOCZ). The hatched area shows the presence of VMEs; the shaded area shows current fishing density between January and March targeting I. argentinus. Catch per Unit Effort contour lines for I. argentinus during the Atlantis 07 and Atlantis 08 surveys (both performed in the month of March) show the potential distribution of the species during its fishing season. The highest yields were found in trawlable areas to the south, overlapping VMEs.

In any case, any potential change of the fishing strategy towards deeper water species (i.e.

Macrourus carinatus, Micromesistus australis, Macruronus magellanicus or Dissostichus

eleginoides) (del Río et al., 2009; 2012), might heavily impact deep-water VMEs located below $300 \mathrm{~m}$ depth. 
In particular, commercial catches of Macrourus carinatus were found to be almost negligible, despite it being the most abundant species in the HSPS, especially between 500 and $1000 \mathrm{~m}$ depth (STECF, 2012). However, the Macrouridae family is of global concern as they are abundant in almost all deep-sea fisheries around the world (Orlov and Iwamoto, 2008), and $M$. carinatus could become a future target species in the HSPS, as is already the case of other deepwater fisheries (Devine et al., 2102). In addition, there is presumed evidence of the high vulnerability of benthic organisms to the indirect mechanical impact produced by sediment removal and re-suspension from near-bottom trawling operations (Bradshaw et al., 2012; Portela et al., 2015), although these effects in the high seas of the Patagonian Shelf remain unknown.

Fishing strategy knowledge may help to support the management and protection of VMEs in these waters. Monitoring of fishery trends might help managers to implement and/or improve mitigation measures aimed at protecting VMEs from future potential bottom trawling impacts in the HSPS.

In combination with protocols for the identification of likely VMEs from commercial fisheries data (Parker et al., 2009; FAO, 2009; Yesson, et al., 2012; Taylor et al., 2013), the proposed approach to identify potential overlaps between VMEs and seasonal fishing activity can be useful in data-scarce high seas fishing grounds where on-board observer records or skippers' logbooks are the only data sources of information about the fishing activity.

In the particular case of the high seas of the Patagonian Shelf there is no RFMO, or any internationally adopted VME conservation and management measures, and thus the responsibility falls on the states concerned. The European Union established regulations for protecting VMEs in the high seas from bottom trawling activities (Council Regulation EC 734/2008), requiring flag States to undertake an impact assessment and develop management plans regarding VMEs (Thomson et al. 2017). Following this regulation and based on scientific advice (Portela et al., 2012), the Spanish Government unilaterally closed high seas areas in the 
region to bottom fishing by Spanish vessels from 1 July 2011 (Thomson et al. 2017). However, it is difficult to determine the catches made in these waters or what other countries are currently involved in bottom fishing activities in the area, since FAO fisheries statistics, the main source of information, do not differentiate between catches in national or high seas waters (Bensch et al., 2009).

Further cooperation in the management of high sea fisheries from the countries concerned would be required to ensure the long term sustainability of VMEs in the region, as stated in the LOS Convention, Article 118, requesting countries involved to "enter into negotiations with a view to taking measures necessary for the conservation of the living resources concerned".

\section{Conclusion}

Commercial fishing data, together with the estimated distribution of VMEs, can be highly useful for monitoring and anticipating future overlapping risks between fisheries and VMEs.

Understanding the fishing pattern of a trawling fleet (i.e. identification of main fishing seasons based on species catch and presence and expert knowledge of the fishery and the resources) is a key factor in developing effective management measures, estimating resource abundance trends and inferring long-term effects from commercial fishing data (from either observers or logbook data) in data poor situations or when stock status knowledge is limited.

In the case of the Spanish trawling fleet operating in the high seas of the Southwest Atlantic, even though long-term fishing effort has fluctuated due to the political context, a clear annual pattern arises, showing three main fishing seasons along the year, mainly driven by two factors: (i) target species migration patterns, and (ii) the delivery of fishing licenses in Falklands/Malvinas waters. 
Although a number of commercially valuable species are fished in these waters, two species are mainly targeted in the high seas: Illex argentinus from January to March, and Merluccius hubbsi from April to September. A significant long-term coupling between both species in the area has been found.

Even though the distribution of potential target species such as Patagonotothen sp. should not pose a future problem, high densities of $I$. argentinus below $300 \mathrm{~m}$ depth in suitable trawling areas where VMEs occur and a hypothetical future development of the Macrourus fishery in the region may pose future threats that should be addressed.

The Spanish Government, in the absence of an RFMO in the Southwest Atlantic Ocean, and following both the mandate from the European Union and recommendations from the UNGA and FAO, has implemented unilateral bottom trawl restrictions on the Spanish bottom trawling fleet operating in the high seas of the Patagonian Shelf. This measure is based on a series of scientific surveys and scientific advice. However, due to the lack of information regarding bottom trawling activities from other countries in the area, further cooperation in the management of the high seas fisheries should be achieved by the countries involved in order to effectively manage and prevent damage to VMEs present in the region.

\section{Acknowledgments}

This study has been funded by the Ministerio de Educación y Ciencia, Government of Spain, through the grant program "Formación de Personal Investigador del Instituto Español de Oceanografia (IEO)". It would have not been possible without the efforts and dedication of the on-board observers over the years in collecting the data for the Southwest Atlantic fisheries program of the IEO. Thanks to all of them.

David Conesa and Antonio López-Quílez would like to thank the Ministerio de Economía y Competitividad (the Spanish Ministry of Economy and Competitiveness) for its support in the 
form of the research grant MTM2016-77501-P (jointly financed with the European Regional

Development Fund).

\section{References}

Acha, E. M., Mianzan, H. W., Guerrero, R. A., Favero, M., and Bava, J. 2004. Marine fronts at the continental shelves of austral South America: physical and ecological processes. Journal of Marine systems, 44: 83-105.

Agnew, D. J., Hill, S.L., Beddington, J.R., Purchase, L.V., and Wakeford, R.C. 2005. Sustainability and management of Southwest Atlantic squid fisheries. Bulletin of Marine Science, 76: 579-593.

Arkhipkin, A.I., Middleton, D.A. J., Portela, J.M., and Bellido, J.M. 2003. Alternative usage of common feeding grounds by large predators: the case of two hakes (Merluccius hubbsi and M. australis) in the southwest Atlantic. Aquatic Living Resources, 16: 487-500.

Arkhipkin, A.I., Brickle, P., and Laptikhovsky, V.V. 2013. Links between marine fauna and oceanic fronts on the Patagonian Shelf and Slope. Arquipelago - Life and marine Sciences, 30: $19-37$.

Basson, M., Beddington, J.R., Crombie, J.A., Holden, S.J., Purchase, L.V., and Tingley, G.A. 1996. Assessment and management techniques for migratory annual squid stocks: the Illex argentinus fishery in the Southwest Atlantic as an example. Fisheries Research, 28: 3-27.

Bensch, A., Gianni, M., Gréboval, D., Sanders, J.S. \& Hjort, A. 2009. Worldwide review of bottom fisheries in the high seas. FAO Fisheries and Aquaculture Technical Paper. No. 522, Rev.1. Rome. 145 pp. ftp://ftp.fao.org/docrep/fao/012/i1116e/i1116e.pdf.

Bjørndal, T. and Munro, G. 2007. Shared fish stocks and high seas issues. In Handbook of operations research in natural resources (pp. 181-199). Springer US.

Bradshaw, C., Tjensvoll, I., Sköld, M., Allan, I. J., Molvaer, J., Magnusson, J., ... and Nilsson, H. C. 2012. Bottom trawling resuspends sediment and releases bioavailable contaminants in a polluted fjord. Environmental Pollution, 170, 232-241.

Brunetti, N.E. 1988. Contribución al conocimiento biológico-pesquero del calamar argentino (Cephalopoda, Ommastrephidae, Illex argentinus). Tesis de doctorado en Ciencias Naturales, Universidad Nacional de La Plata, La Plata, Buenos Aires, Argentina: 135pp.

Brunetti, N.E., Ivanovic, M.L., Rossi, G., Elena, B., Benavides, H., Guerrero, R., et al. 2000. JAMARC-INIDEP Joint research cruise on argentine short-finned squid Illex argentinus. January-March 1997. Informe Técnico INIDEP, 34: 36pp.

STECF. 2012. REVIEW OF SCIENTIFIC ADVICE FOR 2012: Consolidated Advice on Fish Stocks of Interest to the European Union (STECF 11-18): (editor: Willy Vanhee). In EUR $25634 \mathrm{EN}-2012$ 
Chang, S.K., Hoyle, S., and Liu, H.I. 2010. Catch rate standardization for yellowfin tuna (Thunnus albacares) in Taiwan's distant-water longline fishery in the Western and Central Pacific Ocean, with consideration of target change. Fisheries Research 107:210-220

Chen, C.S., Chiu, T.S. and Haung, W.B. 2007a. The Spatial and temporal Distribution Patterns of the Argentine Short-Finned Squid, Illex argentinus, Abundances in the Southwest Atlantic and Effects of Environmental influences. Zoological Studies, 46: 111-122.

Chen, C.S., Haung, W.B., and Chiu, T.S. 2007b. Different Spatiotemporal distribution of Argentine Short-Finned Squid (Illex Argentinus). Zoological Studies, 46: 362-374.

Chen, C.S., and Chiu, T.S. 2009. Standardising the CPUE for the Illex argentinus fishery in the Southwest Atlantic. Fisheries Science, 75: 265-272.

Ciechomski, J.D., Sanchez, R.P., Ehrlich, M.D. and Lasta, C.A. 1979. Distribucion de huevos y larvas de merluza (Merluccius hubbsi) en el Mar Argentino en diferentes epocas del año y evaluación de sus efectivos adultos desovantes. Contribución INIDEP (Mar del Plata), No 380: $1-12$.

Cleveland, W.S. 1979. Robust Locally Weighted Regression and Smoothing Scatterplots. Journal of the American Statistical Association. 74: 829-836.

Davies A.J., Roberts J.M., Hall-Spencer J. 2007. Preserving deep-sea natural heritage: Emerging issues in offshore conservation and management. Biological Conservation 138: 299312.

del Río, J.L., Portela, J., Sacau, M., Patrocinio, T. 2008. Informe de la Campaña de Investigación Pesquera ATLANTIS 2008. Departamento de Pesquerías Lejanas. Informe Interno Instituto Español de oceanografía: 118pp.

del Río, J.L., Portela, J., Patrocinio, T. 2009. Informe de la Campaña de Investigación Pesquera ATLANTIS 2009. Departamento de Pesquerías Lejanas. Informe Interno Instituto Español de oceanografía: 158pp.

del Rio, J.L., Acosta-Yepes, J., Cristobo, J., Martinez, J., Parra-Descalzo, S., Tel, E., Viñas, L., Muñoz, A., Vilela, R., Jimenez, E.E. and Patrocinio, T. 2012. Estudio de los Ecosistemas Marinos Vulnerables en aguas internacionales del Atlántico Sudoccidental. Temas de Oceanografía 6. Ed. Instituto Español de Oceanografía. Ministerio de Economía y Competitividad. 242 pp.

Devine, J.A., Watling, L., Cailliet, G., Drazen, J., Muñoz, P.D., Orlov, A.M., Bezaury, J., 2012. Evaluation of potential sustainability of deep-sea fisheries for grenadiers (Macrouridae). Journal of Ichthyology, 52: 709-721.

EC, 2010, Commission Decision of 1 September 2010 on criteria and methodological standards on good environmental status of marine waters. Official Journal of the European Union 2.9.2010 L 232, 14-24.

Escalle, L., Pennino, M.G., Gaertner, D., Chavance, P., Delgado de Molina, A, H Demarq, H., Romanov, E and Merigot, B. 2016. Environmental Factors and Megafauna Spatio-Temporal Co-Occurrence with Purse-Seine Fisheries. Fisheries Oceanography 25: 433-47. 
ESRI 2016. ArcGIS Desktop: Release 10.3.1. Redlands, CA: Environmental Systems Research Institute.

Falkland Islands Government. 2014. Fisheries Department Fisheries Statistics, Stanley, FIG Fisheries Department. Volume 18, 2013: 100pp

FAO. 2008. Technical consultation on international guidelines for the management of deep-sea fisheries in the high seas. Rome, 4-8 February 2008. TC: DSF/2008/Inf. 3.33 pp.

FAO. 2009. International Guidelines for the Management of Deep-Sea Fisheries in the High Seas. Food and Agricultural Organisation of the United Nations, Rome, Italy, 73pp. Available from: http://www.fao.org/docrep/011/i0816t/i0816t00.htm

Freiwald, A. and Roberts, J. M. (Eds.). 2006. Cold-water corals and ecosystems. Springer, Heidelberg.

Haimovici, M. and Álvarez-Pérez, J. A. 1990. Distribución y maduración sexual del calamar argentino, Illex argentinus (Castellanos, 1960)(Cephalopoda: Ommastrephidae), en el sur de Brasil. Scient. Mar., 54: 179-185.

Haimovici, M., Brunetti, N.E., Rodhouse, P.G., Csirke, J. y Leta, R.H. 1998. Illex argentinus . In Rodhouse, P.G., Dawe, E.G. and O'Dor, R.K. (Eds). Squid recruitment dynamics. (pp. 2758). FAO Fisheries Technical Paper, No. 376. 273 p.

Hall-Spencer, J., Allain, V., Fosså, J.H., 2002. Trawling damage to Northeast Atlantic ancient coral reefs. Proceedings of the Royal Society of London B: Biological Sciences, 269: 507-511.

Hilborn, R. and Walters, C.J. 1992. Quantitative Fisheries Stock Assessment: Choice Dynamics and Uncertainty. New York, USA: Chapman and Hall, 570p.

Jabeur, C., Gobert, B., Missaoui, H. 2000. Typologie de la flottile de peche cotiere dans le golfe de Gabes (Tunisie). Aquatic Living Resources, $13: 421-428$.

Kendall, M.G. 1955. Rank Correlation Methods. New York: Hafner Publishing Co.

Koslow, J. A., Boehlert, G. W., Gordon, J. D. M., Haedrich, R. L., Lorance, P., Parin, N. 2000 Continental slope and deep-sea fisheries: implication for a fragile ecosystem. ICES Journal of Marine Sciences, 57: 548-557.

Koslow, J. A., Gowlett-Holmes, K., Lowry, J. K., O’Hara, T., Poore, G. C. B., Williams, A. 2001. Seamount benthic macrofauna off southern Tasmania: community structure and impacts of trawling. Marine Ecology Progress Series, 213: $111-125$.

Lehodey P., Bertignac M., Hampton J., Lewis T., Picaut J. 1997. El Niño-southern oscillation and Tuna in the western Pacific. Nature 389:715-718.

Louge, E., Reta, R., Santos, B., Hernandez, D. 2009. Distribution of the Argentine hake (Merluccius hubbsi Marini, 1933) in the Argentine Sea (41-48 S) in relation to oceanographic parameters during winter (1996-2003). Revista de Biología marina y Oceanografía, 44: 497510. 
Lunn, K. E., and Dearden, P. 2006. Monitoring small-scale marine fisheries: An example from Thailand's Ko Chang archipelago. Fisheries Research, 77: 60-71.

Macchi, G.J., Pájaro, M. and Ehrlich, M. 2004. Seasonal egg production pattern of the Patagonian stock of Argentine hake (Merluccius hubbsi). Fisheries Research, 67: 25-38.

Macchi, G.J., Pájaro, M., and Dato, C. 2007. Spatial variations of the Argentine hake (Merluccius hubbsi (Marini, 1933)) spawning shoals in the Patagonian area during a reproductive season. Revista de Biología marina y Oceanografía, 42: 345-356.

Macchi, G. J., Martos, P., Reta, R., and Dato, C. 2010. Offshore spawning of the Argentine hake (Merluccius hubbsi) Patagonian stock. Pan-American journal of Aquatic Sciences. 5: 22-35.

Maunder, M.M., and Punt, A.E., 2004. Standardizing catch and effort data: a review of recent approaches. Fisheries Research. 70, 141- 149.

Orlov, A.M. and Iwamoto, T. 2008. Grenadiers of the World Oceans: Biology, Stock Assessment, and Fisheries, American Fisheries Society Symposium 63. Eds. Bethesda, American Fisheries Society.

Otero, H.O., and Kawai, T. 1981. The stock assessment on common hake (Merluccius hubbsi) in the south-west Atlantic. Bull. Tokai Reg. Fish. Res. Lab., 104: 35-53.

Pájaro, M., Macchi, G.J., and Martos, P. 2005. Reproductive pattern of the patagonian stock of Argentine hake, Merluccius hubbsi. Fisheries Research, 72: 97-108.

Paradinas, I, Conesa, D, Pennino, MG, Muñoz, F, Fernandez, AM, López-Quílez, A, and Bellido, JM. 2015. A Bayesian Spatio-temporal approach to identifying fish nurseries by validating persistence areas. Marine Ecology Progress Series, 528: 245-255.

Paradinas, I., Conesa, D., López-Quílez, A., and Bellido, J. M. 2017. Spatio-Temporal model structures with shared components for semi-continuous species distribution modelling. Spatial Statistics. http://dx.doi.org/10.1016/j.spasta.2017.08.001

Parker, S.J., Penney, A.J., Clark, M.R. 2009. Detection criteria for managing trawl impacts on vulnerable marine ecosystems in high seas fisheries of the South Pacific Ocean. Marine Ecology Progress Series, 397: 309-317.

Pelletier, D. and Ferraris, J. 2000. A multivariate approach for defining fishing tactics from commercial catch and effort data. Canadian Journal of Fisheries and Aquatic Sciences, 57: 5165

Pennino, M.G., Muñoz, F., Conesa, D., Lopez-Quilez, A., Bellido, J.M. 2014. Bayesian spatiotemporal discard model in a demersal trawl fishery. Journal of Sea Research, 90: 44-53

Podestá, G. P. 1990. Migratory Pattern of Argentine hake Merluccius hubbsi and oceanic processes in the Southwestern Atlantic Ocean. Fisheries Bulletin, 88: 167-177.

Portela, J., Contreras, N. and Trujillo, V. 1997. Aspectos reproductivos del calamarete (Loligo gahi), el calamar (Illex argentinus) y la merluza (Merluccius hubbsi) en el Atlántico Sudoccidental. Informe. Técnico IEO, 165, 45pp. 
Portela, J.M., Bellido, J.M., Cardoso, X.A., Wang, J., Ulloa, E., Tato, V., and Otero, M.G. 2002. Analysis of the evolution of hake (Merluccius hubbsi and Merluccius australis) catch and effort by Spanish vessels operating in the Patagonian shelf area since the beginning of this industrial fishery. ICES CM 2002/L: 05.

Portela, J.M., Sacau, M., Wang, J., Pierce, G.J., Santos, M.B., and Cardoso, X. 2005a. Analysis of the variability in the abundance of shortfin squid (Illex argentinus) in the Southwest Atlantic fisheries during the period 1999-2004. ICES CM 2005/O:16.

Portela, J., Pierce, G. J., Agnew, D., Arkhipkin, A., Medina, I., Sacau-Cuadrado, M. D. M., Santos, M.B., et al. 2005b. Promoting higher added value to a finfish species rejected to sea. Cooperative research (CRAFT) Technical report. 332pp

Portela, J.M. 2009. Informe sobre Zonas de Pesca de la Flota Española en el Atlántico SW. Working group of the Long Distance Fleet Regional Advisory Council (LDRAC). Santiago de Compostela. 13th March 2009.

Portela, J.M, Acosta, J., Parra, S., Cristobo, J., Tel, E., del Rio, J.L., Muñoz, A., et al. 2010. Informe preliminar sobre Ecosistemas Marinos Vulnerables en aguas internacionales del Atlántico Sudoccidental y de las posibles interacciones con las actividades pesqueras. Informe Interno del Instituto Español de oceanografía.

Portela, J., Muñoz, A., Almón, B., Tel, E., Cristobo, J., Del Río, J.L., Acosta, J., et al. 2012. Management strategies to limit the impact of bottom trawling on VMEs in the high seas of the SW Atlantic. INTECH Open Access Publisher.

Portela, J., Cristobo, J., Ríos, P., Acosta, J., Parra, S., Del Río, J. L., et al. 2015. A first approach to assess the impact of bottom trawling over vulnerable marine ecosystems on the high seas of the Southwest Atlantic. Biodiversity in ecosystems - Linking Structure and Function. Dr. Juan A. blanco (Ed.), InTech, 28.

R Core Team, 2017. R: A language and environment for statistical computing. R Foundation for Statistical Computing, Vienna, Austria URL http://www.R-project.org/.

Rodhouse, P.G., Barton, J., Hatfield, E.M.C., and Symon, C., 1995. Illex argentinus: life cycle, population structure and fishery. ICES Marine Science Symposia, 199: 425-432.

Roper, C.F.E., and Young, R. E., 1975). Vertical distribution of pelagic cephalopods. Smithsonian contributions to zoology, no. 209. Washington, DC, USA: Smithsonian Institution Press, 51pp.

Sabatini, M.E. and Colombo, G.L.A. 2001. Seasonal pattern of zooplankton biomass in the Argentinian shelf off Southern Patagonia $\left(45^{\circ}-55^{\circ}\right.$ S). Scientia Marina, 65: 21-31.

Sacau, M., Pierce, G.J., Wang, J., Alexander, I., Arkhipkin, A.I., Portela, J., Brickle, P. et al. 2005. The spatio-temporal pattern of Argentine shortfin squid Illex argentinus abundance in the south- west Atlantic. Aquatic Living Resources, 18: 361-372.

Taylor, M. L., Yesson, C., Agnew, D. J., Mitchell, R. E. and Rogers, A. D. 2013. Using fisheries by-catch data to predict octocoral habitat suitability around South Georgia. J. Biogeography, 40: 1688-1701. 
Thompson, A., Sanders, J., Tandstad, M., Carocci, F. and Fuller, J. 2017. Vulnerable marine ecosystems: processes and practices in the high seas. FAO Fisheries and Aquaculture Technical Paper (FAO). No. 595.

Tzanatos, E., Dimitriou, E., Katselis, G., Georgiadis, M., and Koutsikopoulos, C. 2005. Composition, temporal dynamics and regional characteristics of small-scale fisheries in Greece. Fisheries Research, 73: 147-158.

UNGA (2007). Resolution 61/105 Sustainable fisheries, including through the 1995 Agreement for the Implementation of the Provisions of the United Nations Convention on the Law of the Sea of 10 December 1982 relating to the Conservation and Management of Straddling Fish Stocks and Highly Migratory Fish Stocks, and related instruments. UNGA A/RES/61/105. Available from: http://www.un.org/Depts/los/general_assembly/general_assembly_reports. htm, $21 \mathrm{pp}$

UNGA (2009). Resolution 64/72. Sustainable fisheries, including through the 1995 Agreement for the Implementation of the Provisions of the United Nations Convention on the Law of the Sea of 10 December 1982 relating to the Conservation and Management of Straddling Fish Stocks and Highly Migratory Fish Stocks, and related instruments. UNGA A/RES/64/72. Available as General Assembly document A/64/L.29. Available from: http://daccessddsny.un.org/doc/UNDOC/GEN/N09/466/15/PDF/ N0946615.pdf?OpenElement, 26pp

Waluda, C.M., Trathan, P.N. and Rodhouse, P.G. 1999. Influence of oceanographic variability on recruitment in the genus Illex argentinus (Cephalopoda: ommastrephidae) fishery in the South Atlantic. Marine Ecology Progress Series, 183: 159-167.

Waluda, C.M., Rodhouse, P. G. and Trathan, P.N. 2001. Remotely sensed mesoscale oceanography and the distribution of Illex argentinus: towards operational squid fisheries oceanography in the South Atlantic. Fisheries oceanography, 10: 207-216.

Wang, J. Pierce, G.J., Sacau, M., Portela, J., Santos M.B., Cardoso, X., and Bellido, J.M. 2007. Remotely sensed local oceanic thermal features and their influence on the distribution of hake (Merluccius hubbsi) at the Patagonian shelf edge in the SW Atlantic. Fisheries Research, 83, 133-144.

Wickham, H. 2016. ggplot2: elegant graphics for data analysis. Springer.

Winter, A., Laptikhovsky, V., and Brickle, P. 2010. Rock cod (Patagonotothen ramsayi (Regan, 1913)) stock assessment in the Falkland Islands. Falkland Islands Government Fisheries Department, Stanley. 12pp.

Yesson, C., Taylor, M. L., Tittensor, D. P., Davies, A. J., Guinotte, J., Baco, A., Black, J., HallSpencer, J. M. and Rogers, A. D. 2012. Global habitat suitability of cold-water octocorals. Journal of Biogeography, 39: 1278-1292

Zuur, A.F., Ieno, E.N. and Smith, G.M. 2007. Analysing Ecological Data. New York, USA: Springer, 672pp.

Zuur A.F., Ieno, E.N., and Elphick, C.S. 2010. A protocol for data exploration to avoid common statistical problems. Methods in Ecology \& Evolution, 1: 3-14. 